\title{
DOES CORPORATE SOCIAL RESPONSIBILITY AFFECT EARNINGS MANAGEMENT? EVIDENCE FROM THE INDONESIAN BANKING INDUSTRY
}

\author{
Doddy SETIAWAN ${ }^{1}$, Ronny PRABOWO ${ }^{2}$, Vina ARNITA ${ }^{3}$, Anas WIBAWA ${ }^{4}$ \\ ${ }^{1,4}$ Universitas Sebelas Maret, Surakarta, Indonesia \\ ${ }^{2}$ Universitas Kristen Satya Wacana, Salatiga, Indonesia \\ ${ }^{3}$ Universitas Pembangunan Panca Budi, Medan, Indonesia \\ E-mails: ${ }^{1}$ doddy.setiawan@staff.uns.ac.id (corresponding author); ${ }^{2}$ ronny.prabowo@uksw.edu; \\ 3vinaarnita@dosen.pancabudi.ac.id; ${ }^{4}$ anasw73@gmail.com
}

Received 06 March 2019; accepted 10 June 2019

\begin{abstract}
This paper aims at examining the effect of corporate social responsibility on earnings management in the Indonesian banking industry. Using Indonesian publicly listed banking firms in the years of 2013-2015 as the sample, we generate 94 firmyear observations as the final sample. The results show that corporate social responsibility positively affects earnings management, suggesting that the higher the corporate social responsibility score, the greater earnings management. Further, the study investigates the effects of corporate social responsibility on absolute earnings management, positive earnings management, and negative earnings management. The results robustly demonstrate the positive effects of corporate social responsibility on earnings management. Thus, this study implies that investors need to be cautious of banks that engage in higher corporate social responsibility because they are more likely to exhibit greater earnings management. While most of the previous studies in this issue focus on developed countries as their research settings, this study provides empirical evidence on the relationship between corporate social responsibility in Indonesia as an emerging market.
\end{abstract}

Keywords: corporate social responsibility, earnings management, discretionary accrual, banking, disclosure, Indonesia.

JEL Classification: M41, G21.

\section{Introduction}

There are two important regulations regarding corporate social responsibility in Indonesia, namely Law Nu.40/2007 on limited liability corporation and Law Nu.25/2007 on investment. Law Nu.40/2007 article 74 requires firms that operate in natural resources-related activities to engage in corporate social responsibility. The law requires firms to allocate a portion of their funds for corporate social responsibility; otherwise, they will be sanctioned by the government. This regulation implies that corporate social responsibility has cost implications for firms. Further, Law $\mathrm{Nu} .25 / 2007$ article 15 also stipulates that firms engage in corporate social responsibility. Both Law Nu.40/2007 and Law Nu.25/2007 emphasize the importance of corporate social responsibility in Indonesia.
Previous studies on the corporate social responsibility in Indonesia investigate the effect of corporate social responsibility on firm performance (Fauzi and Idris 2009, Oeyono et al. 2011, Sarumpaet 2006), how investors incorporate corporate social responsibility in their investment decisions (Awuy et al. 2016, Fitriani and Setiany 2014) and the determinants of corporate social responsibility (Setiawan et al. 2018, Siregar and Yanivi 2010). However, there are still few studies analyzing how corporate social responsibility affects the quality of the financial statement. Therefore, this study investigates the effect of corporate social responsibility on earnings management.

Using the Canadian context, Gargouri et al. (2010) find that corporate social responsibility is positively related to earnings management, implying that the higher score

Copyright @ 2019 The Authors. Published by VGTU Press.

This is an Open Access article distributed under the terms of the Creative Commons Attribution License (http://creativecommons.org/licenses/by/4.0/), which permits unrestricted use, distribution, and reproduction in any medium, provided the original author and source are credited.. 
corporate social responsibility increases the earnings management activity. This study confirms Grougiou et al. (2014) who find that US banks that engage in earnings management intensively involved in corporate social responsibility. On the other hand, Kim et al. (2012) demonstrate that higher corporate social responsibility is associated with less accrual and real earnings management. The results show that firms with higher corporate social responsibility activities exhibit a greater ethical level and therefore are less likely to engage in earnings management. Further, studies using US larger firms also show that firms that have higher corporate social responsibility score are less likely to engage in earnings management (Hong and Andersen 2011). The results are in line with Cho and Chun (2016) who find the negative effect of corporate social responsibility on real earnings management by using Korean firms as their sample. Further, using cross-country data, MartínezFerrero et al. (2015) and Scholtens and Kang (2013) show the negative relationship between corporate social responsibility and earnings management. Meanwhile, Liu et al. (2017) find no significant relationship between corporate social responsibility and earnings management. Thus, these previous studies suggest that the relationship between corporate social responsibility and earnings management is inconclusive. Therefore more studies in this area are needed (Grougiou et al. 2014, Kim et al. 2012).

Previous studies on the relationship between corporate social responsibility and earnings management mostly rely on cross-country data or use developed countries, such as the US and Canada, as the research context. Therefore, the study investigates the relationship between corporate social responsibility and earnings management using the Indonesian data as an example of an emerging market. It will highlight how corporate social responsibility affects earnings management in an emerging market. Second, studies in this area mostly focus on non-financial firms. While banking firms arguably have different characteristics from non-financial firms. Further, Indonesian banks have a significant role in economic activity and are an important element of financial stability (Hidayat et al. 2012). The Indonesian banking industry also exhibited positive growth in 2017, and it will have a positive effect on Indonesia economics (Statistics_Indonesia 2018). Grougiou et al. (2014) also suggest more research on corporate social responsibility in the banking industry. Therefore, this study focuses on the effect of corporate social responsibility and earnings management in the Indonesian banking industry.

\section{Literature review and hypothesis development}

Three arguments that underlie the relationship between corporate social responsibility and earnings management predict the positive, negative, and no significant relationship between both variables (Grougiou et al. 2014). The stakeholder theory argues that firms need to address the interests of all stakeholders, including shareholders, regulators, and governments (Donaldson and Preston 1995, Roberts 1992). Managers need to address stakeholders' various interests but at the same time have to prioritize the interests they consider important. Meanwhile, stakeholders have competing interests that potentially create tensions because managers have intense pressure to serve various stakeholders' interests. Another important feature of the stakeholder theory is a high information asymmetry between managers and stakeholders (Grougiou et al. 2014). Managers have more firm-level information than other stakeholders. In this situation, managers have greater opportunities to engage in earnings management to fulfill shareholder interests. Grougiou et al. (2014) argue that managers who aim to satisfy diverse stakeholders' interests by engaging in corporate social responsibility are also more likely to involve in earnings management activity. The stakeholder's theory predicts that corporate social responsibility has a positive effect on earnings management.

Chih et al. (2008) propose the myopia avoidance theory to explain the relationship between corporate social responsibility and earnings management. This hypothesis argues that firms that engage in corporate social responsibility activity have higher ethics in their business activities. In this respect, firms will provide better-quality financial statements to their shareholders. Thus, managers avoid earnings management because it is considered an unethical decision (Shafer 2015). Another argument of the myopia avoidance hypothesis is managers not only work for financial purposes but also social purposes. Therefore, managers will provide higher-quality financial statements. Myopia avoidance hypothesis predicts the negative effect of corporate social responsibility on earnings management.

The third theory regarding the relationship between corporate social responsibility and earnings management is the institutional theory (Chih et al. 2008). This theory argues that corporate social responsibility may be a product of institutional factors. Therefore, corporate social responsibility might not have a relationship with earnings management. The institutional theory predicts that there is no significant effect of corporate social responsibility on earnings management.

Using US sample firms, Kim et al. (2012) analyze the effect of corporate social responsibility on accrual and real earnings management. The results suggest that firms that engage in high corporate social responsibility activity exhibit less accrual and real earnings management. Corporate social responsibility provides incentives for managers to increase the quality of financial statements. The findings confirm the myopia avoidance theory (Chih et al. 2008). Kim et al. (2012) are in line with Hong and Andersen (2011) 
who find the positive effect of corporate social responsibility on earnings quality. A further test by Cho and Chun (2016) using the Korean context also reveals the negative effect of corporate social responsibility performance on real activity earnings management. Using the Spanish context, GrasGil et al. (2016) also find a negative relationship between corporate social responsibility and earnings management. Spanish managers engage in corporate social responsibility as their ethical decisions. Therefore, managers prefer to avoid unethical actions such as earnings management. Analyzing 139 firms from ten Asian countries, Scholtens and Kang (2013) demonstrate that CSR negatively affects earnings management. Firms with better corporate social responsibility performance are less likely to engage in earnings management. Thus, firms with better corporate social responsibility exhibit better financial statements. A study on European countries by Alsaadi et al. (2017) also find that corporate social responsibility has a negative relationship with earnings management. Further, the quasi-experiment of Wang et al. (2018) indicates that corporate social responsibility regulation constrains managers in engaging in earnings management in China.

Liu et al. (2017) investigate the effect of corporate social responsibility on earnings management and suggest that corporate social responsibility has no significant effect on earnings management. The results confirm the institutional theory (Chih et al. 2008). An institutional aspect that explains the relationship between corporate social responsibility and earnings management is family ownership because the relation between corporate social responsibility and earnings management is not significant when Liu et al. (2017) control for the family involvement. They underscore the importance of family ownership in firm decisions (Setiawan et al. 2016, Untoro et al. 2017). Sun et al. (2010) also find no significant effect of environmental disclosure on earnings management. Therefore, Liu et al. (2017) and Sun et al. (2010) support the institutional theory.

Gargouri et al. (2010) investigate the relationship between corporate social responsibility and earnings management by using Canadian firms as their sample. Their results suggest that there is a positive relationship between corporate social responsibility rating and earnings management. Firms with higher corporate social responsibility rating engage aggressively in earnings management, and their managers are better able to exploit the information asymmetry between managers and stakeholders. In a similar vein, Muttakin et al. (2015) find that corporate social responsibility leads to higher earnings management. Managers engage in income-increasing earnings management to give a good impression to their stakeholders.

Further, Prior et al. (2008) indicate that firms that engage in earnings management use corporate social responsibility activity to cover earnings management, implying that there is a positive relationship between earnings management and corporate social responsibility. Managersopportunistic behaviors have negative effects on firms' financial performance. Thus, Gargouri et al. (2010), Muttakin et al. (2015) and Prior et al. (2008) support the stakeholder theory.

Previous studies on the effect of corporate social responsibility and earnings management largely focus on non-financial firms, with Grougiou et al. (2014) who use US banking firms as an exception. Grougiou et al. (2014) show that earning management has a positive effect on corporate social responsibility activity. Banks that engage in more aggressive earnings management exhibit greater corporate social responsibility. Thus, managers use corporate social responsibility to conceal the effect of earnings management. The results show that there is a positive relationship between corporate social responsibility and earnings management. This study focuses on the effect of corporate social responsibility on earnings management in the context of the Indonesian banking industry. We predict that managers who engage in more corporate social responsibility will increase earnings management practice (Gargouri et al. 2010; Muttakin et al. 2015, Prior et al. 2008). Therefore the hypothesis is

H1: Corporate social responsibility has a positive effect on earnings management.

\section{Research methods}

Our sample is Indonesian banks that were listed at the Indonesian Stock Exchange for the years 2013-2015, resulting in 94 bank-year observations. This study uses earnings management as the dependent variable and corporate social responsibility as the independent variable. We follow Beaver and Engel (1996) in measuring earnings management by using discretionary accrual. Beaver and Engel (1996) develop a specific measurement of earnings management in the context of the banking industry through loan loss provision.

The independent variable of the study is corporate social responsibility. The study applies the Global Reporting Index (GRI) index as a proxy of corporate social responsibility. The GRI index uses content analysis. Further, the index divides into six categories: economy, environment, labor, human right, society, and product responsibility. Further, we use four control variables in the study, namely growth, firm size, profitability, audit firm, and leverage. Growth is measured by the market to book ratio. We measure firm size, profitability, and leverage using total assets, profitability ROE (return on equity), debt to assets ratio, respectively. Lastly, the study applies a dummy variable as a proxy of the audit firm variable that is equal to one if the bank's audit firm is a Big-4 audit firm and zero otherwise.

This study uses the following equation to test our hypothesis: 


$$
\begin{gathered}
\mathrm{EM}_{\mathrm{it}}=\alpha+\beta_{1} \mathrm{CSR}+\beta_{2} \mathrm{PBV}+\beta_{3} \mathrm{SIZE}+\beta_{4} \mathrm{ROE}+ \\
\beta_{5} \mathrm{LEV}+\beta_{5} \text { Audit }+\mathrm{e},
\end{gathered}
$$

where $\mathrm{EM}$ = earnings management, using Beaver and Engel (1996) method; CSR = corporate social responsibility, using GRI index; $\mathrm{PBV}=$ growth, price to book ratio; SIZE = size of the company, log total assets; $\mathrm{ROE}=$ profitability ratio, return on equity; LEV = leverage, debt to total assets; Audit $=$ audit firms, a dummy variable one if the audit firm is Big-4 and zero otherwise.

\section{Results and analysis}

Table 1 and Table 2 provide information regarding the descriptive statistics of our variables.

Table 1. Descriptive statistics

\begin{tabular}{|c|c|c|c|c|c|c|}
\hline $\begin{array}{c}\text { Va- } \\
\text { riab- } \\
\text { les }\end{array}$ & $\mathrm{N}$ & $\begin{array}{c}\text { Maxi- } \\
\text { mum }\end{array}$ & $\begin{array}{c}\text { Mini- } \\
\text { mum }\end{array}$ & Mean & Median & $\begin{array}{c}\text { Std } \\
\text { Dev }\end{array}$ \\
\hline Dait & 94 & 0.7567 & -0.0840 & 0.0083 & 0.0031 & 0.0872 \\
\hline CSR & 94 & 29 & 8 & 14.5744 & 14 & 4.7733 \\
\hline SIZE & 94 & 34.4091 & 27.8819 & 31.3243 & 31.3281 & 1.6594 \\
\hline ROE & 94 & 0.9855 & -1.0660 & 0.0918 & 0.0864 & 0.1693 \\
\hline LEV & 94 & 18.2075 & 0.1197 & 7.0015 & 6.7285 & 2.9742 \\
\hline PBV & 94 & 4.1529 & 0.0014 & 1.3098 & 1.0397 & 0.9159 \\
\hline
\end{tabular}

Table 2. The descriptive statistic for the dummy variable

\begin{tabular}{|l|c|}
\hline & Audit \\
\hline Category 1 & 0.6914 \\
\hline Category 0 & 0.3086 \\
\hline
\end{tabular}

The mean (median) value of earnings management is 0.0083 (0.0031), suggesting that Indonesian banks engage in income-increasing earnings management to increase their performance. Further, the current study shows that the mean (median) value of the CSR index is $14.57 \%$ (14\%). Meanwhile, the maximum value and the minimum values of CSR are 29 and 8, respectively. The results show that Indonesian banks have lower CSR disclosure. Further, on average Indonesian banks have positive ROE (0.0086) and ROE ranges between -1.0660 to 0.9885 . The average price to book value is 1.3098 , implying that the share prices of Indonesian banks are higher than their book value of equity. Most of Indonesia banks (69.14\%) are audited by Big-4 audit firms.

\section{Analysis}

Table 3 provides the results of our statistical testing. The first column shows the effect of CSR on earnings management. Further, the study investigates the effects of sub-indexes of
CSR on earnings management. Table 3 also displays that CSR has a positive effect on earnings management. Firms with higher CSR disclosure engage in greater earnings management activity. Our results confirm the stakeholder theory (Donaldson and Preston 1995, Roberts 1992). Managers use information asymmetry between managers and stakeholders to exploit their stakeholders through accrual earnings management (Grougiou et al. 2014). The study confirms previous studies such as, Grougiou et al. (2014), Muttakin et al. (2015) and Prior et al. (2008) who find the positive effect of CSR on earnings management. However, the study is not in line with previous studies of Cho and Chun (2016), Hong and Andersen (2011), and Kim et al. (2012) who demonstrate the negative effect of CSR on earnings management. Further, we cannot confirm the myopia avoidance theory (Chih et al. 2008) that predicts that CSR leads to better earnings quality. Further, our results also do not confirm institutional theory (Chih et al. 2008) that predicts insignificant relation between CSR and earnings management (Liu et al. 2017, Sun et al. 2010).

Our results indicate that Indonesian banks exhibit a positive relation between CSR activity and earnings management, suggesting that banks with higher CSR activity are also likely to engage in greater earnings management activity probably due to the pressure from their stakeholders' interests. Indonesian banks aim to serve their stakeholders' diverse interests that lead them to engage in earnings management. As internal stakeholders, managers have more information and control power than other stakeholders. Thus, they are likely to use their discretion to engage in earnings management. Table 1 shows that the mean value of earnings management is 0.0083 , suggesting that Indonesian banks engage in income-increasing earnings management. It is then predicted that CSR activity leads to aggressive earnings management to achieve higher performance.

The study also investigates the effects of each sub-index to earnings management. Table 3 shows that most of the CSR indexes have positive effects on earnings management. Specifically, CSR_1, CSR_2, CSR_3 and CSR_5 positively affect earnings management activity. Subindex CSR_1 represents economic performance. Therefore economic performance increases the probability that banks engage in income-increasing earnings management probably because they are motivated to achieve higher economic performance. Subindex CSR_2 represents environmental performance. Thus, environmental performance positively affects bank to engage in upward earnings management. Subindex CSR_3 and CSR_5 also positively affect earnings management. Thus, labor performance and society performance cause management to engage in greater earnings management. On the other hand, CSR_4 negatively affects earnings management. CSR_4 represents human right performance, implying that banks with higher disclosure on 
human right are less likely to engage in earnings management. Further, CSR_6 does not have a significant effect on management decision to engage in income-increasing earnings management. Changes in responsibility performance disclosure might not effectively influence management to engage in earnings management activity.

The study divides the sample into two categories: banks that engage in income-increasing earnings management and banks that engage in income-decreasing earnings management. Banks that engage in income-increasing earnings management exhibit negative earnings management while banks that engage in income-decreasing earnings management have the negative values of earnings management. There are 52 observations with positive earnings management and 42 observation with negative earnings management. Table 4 provides the result of statistical testing. The results show that CSR has a positive effect on positive earnings management. CSR has motivated managers to engage in income-increasing earnings management aggressively. Further, Table 4 also shows that CSR has a positive effect on negative earnings management. The results suggest that the robustness of the effect of CSR on earnings management in banks that pursue income- decreasing earnings management. CSR also has a positive effect

Table 3. The Results of the statistical testing

\begin{tabular}{|c|c|c|c|c|c|c|c|}
\hline \multicolumn{8}{|c|}{ Earnings management } \\
\hline VARIABLES & FULL & 1 & 2 & 3 & 4 & 5 & 6 \\
\hline \multirow{2}{*}{$\mathrm{C}$} & 0.0089 & -0.4029 & -0.1992 & -0.2239 & -0.4157 & -0.3261 & -0.4204 \\
\hline & $(0.9472)$ & $(0.0090)$ & $(0.0138)$ & $(0.0167)$ & $(0.0071)$ & $(0.0094)$ & $(0.0080)$ \\
\hline \multirow{2}{*}{ CSR } & $0.0080^{\mathrm{b}}$ & & & & & & \\
\hline & $(0.0326)$ & & & & & & \\
\hline \multirow{2}{*}{ CSR_1 } & & $0.0142^{\mathrm{b}}$ & & & & & \\
\hline & & $(0.0204)$ & & & & & \\
\hline \multirow{2}{*}{ CSR_2 } & & & $0.0072^{\mathrm{c}}$ & & & & \\
\hline & & & $(0.0859)$ & & & & \\
\hline \multirow{2}{*}{ CSR_3 } & & & & $0.0183^{c}$ & & & \\
\hline & & & & $(0.0695)$ & & & \\
\hline \multirow{2}{*}{ CSR_4 } & & & & & $-0.0113^{c}$ & & \\
\hline & & & & & $(0.0677)$ & & \\
\hline \multirow{2}{*}{ CSR_5 } & & & & & & $0.0136^{\mathrm{b}}$ & \\
\hline & & & & & & $(0.0119)$ & \\
\hline \multirow{2}{*}{ CSR_6 } & & & & & & & -0.0001 \\
\hline & & & & & & & $(0.4400)$ \\
\hline \multirow{2}{*}{ ROE } & $-0.0318^{\mathrm{a}}$ & $-0.0416^{\mathrm{b}}$ & $-0.0558^{\mathrm{b}}$ & $-0.0289^{c}$ & $-0.0584^{\mathrm{a}}$ & $-0.0545^{\mathrm{b}}$ & $-0.0574^{\mathrm{a}}$ \\
\hline & $(0.0000)$ & $(0.0149)$ & $(0.0069)$ & $(0.0662)$ & $(0.0083)$ & $(0.0148)$ & $(0.0085)$ \\
\hline \multirow{2}{*}{ SIZE } & -0.0042 & $0.0108^{a}$ & $0.0053^{\mathrm{c}}$ & $0.0050^{c}$ & $0.0131^{\mathrm{a}}$ & $0.0098^{\mathrm{a}}$ & $0.0132^{\mathrm{a}}$ \\
\hline & $(0.4737)$ & $(0.0061)$ & $(0.0561)$ & $(0.0841)$ & $(0.0044)$ & $(0.0049)$ & $(0.0051)$ \\
\hline \multirow{2}{*}{ LEV } & -0.0013 & -0.0014 & -0.0006 & -0.0040 & -0.0020 & -0.0016 & -0.0019 \\
\hline & $(0.4066)$ & $(0.4560)$ & $(0.5937)$ & $(0.1505)$ & $(0.2878)$ & $(0.2835)$ & $(0.3051)$ \\
\hline \multirow{2}{*}{ PBV } & 0.0108 & 0.0171 & 0.0135 & 0.0098 & 0.0161 & 0.0164 & 0.0163 \\
\hline & $(0.5436)$ & $(0.4429)$ & $(0.5155)$ & $(0.5742)$ & $(0.4877)$ & $(0.4888)$ & $(0.4811)$ \\
\hline \multirow[b]{2}{*}{ AUDIT } & $0.0183^{\mathrm{a}}$ & $0.0180^{c}$ & 0.0185 & $0.0228^{b}$ & 0.0176 & 0.0132 & 0.0165 \\
\hline & $(0.0068)$ & $(0.0726)$ & $(0.1146)$ & $(0.0112)$ & $(0.1324)$ & $(0.1609)$ & $(0.1186)$ \\
\hline $\begin{array}{l}\text { Adjusted } \\
\text { R-square }\end{array}$ & 0.1521 & 0.0716 & 0.1014 & 0.1436 & 0.0647 & 0.0751 & 0.0633 \\
\hline F statistic & 3.7794 & 2.1949 & 2.7499 & 3.5981 & 2.0722 & 2.2592 & 2.0483 \\
\hline $\begin{array}{c}\text { Prob } \\
\text { (F-statistic) } \\
\end{array}$ & 0.0022 & 0.0510 & 0.0170 & 0.0031 & 0.0646 & 0.0450 & 0.0677 \\
\hline $\mathrm{N}$ & 94 & 94 & 94 & 94 & 94 & 94 & 94 \\
\hline
\end{tabular}


on earnings management for banks with negative earnings management. Thus, our findings demonstrate that the positive effect of CSR on earnings management is robust at the condition of income-increasing earnings management and income- decreasing earnings management. The results, therefore, support stakeholder the theory (Grougiou et al. 2014, Muttakin et al. 2015, Prior et al. 2008) that predict the positive relation between CSR and earnings management.

The study also investigates the effect of CSR on absolute earnings management. Absolute earnings management indicates how banks engage in earnings management regardless of the sign of earnings management. Table 4 also demonstrates the effect of CSR on absolute earnings management. The results suggest that CSR has a positive effect on absolute earnings management. Further, the results imply that CSR leads to aggressive earnings management. Indonesian banks use CSR activities to conceal the effects of their earnings management. Thus, Indonesian banks that engage more in CSR activities are likely to use their discretions to aggressively manage earnings, confirming the positive effect of CSR on earnings management robust for absolute earnings management. Thus, our results confirm the stakeholder theory.

Table 4. The Statistical testing result for positive, negative and absolute earnings management

\begin{tabular}{|c|c|c|c|}
\hline \multicolumn{4}{|c|}{ Earnings Management } \\
\hline VARIABLES & Positive & Negative & Absolute \\
\hline \multirow{2}{*}{$\mathrm{C}$} & 0.2221 & 0.5630 & 0.2005 \\
\hline & $(0.1125)$ & $(0.5630)$ & $(0.0000)$ \\
\hline \multirow{2}{*}{ CSR } & $0.0108^{b}$ & $0.0005^{c}$ & $0.0061^{c}$ \\
\hline & $(0.0400)$ & $(0.0804)$ & $(0.0898)$ \\
\hline \multirow{2}{*}{ ROE } & -0.0112 & $-0.0420^{c}$ & $0.0206^{c}$ \\
\hline & $(0.3305)$ & $(0.0775)$ & $(0.0999)$ \\
\hline \multirow{2}{*}{ SIZE } & $-0.0119^{\mathrm{a}}$ & 0.0007 & $-0.0094^{\mathrm{b}}$ \\
\hline & $(0.0060)$ & $(0.7474)$ & $(0.0121)$ \\
\hline \multirow{2}{*}{ LEV } & -0.0024 & -0.0007 & -0.0007 \\
\hline & $(0.2154)$ & $(0.2833)$ & $(0.5802)$ \\
\hline \multirow{2}{*}{ PBV } & 0.0234 & $-0.0066^{\mathrm{a}}$ & 0.0231 \\
\hline & $(0.3773)$ & $(0.0077)$ & $(0.1692)$ \\
\hline \multirow{2}{*}{ AUDIT } & 0.0091 & 0.0079 & 0.0134 \\
\hline & $(0.5838)$ & $(0.1076)$ & $(0.2121)$ \\
\hline $\begin{array}{l}\text { Adjusted } \\
\text { R-square }\end{array}$ & 0.1518 & 0.0136 & 0.1154 \\
\hline F statistic & 2.5211 & 1.0941 & 3.0211 \\
\hline $\begin{array}{c}\text { Prob } \\
\text { (F-statistic) }\end{array}$ & 0.0345 & 0.3852 & 0.0099 \\
\hline $\mathrm{N}$ & 52 & 42 & 94 \\
\hline
\end{tabular}

\section{Conclusions}

The study investigates the effect of CSR on earnings management using listed Indonesian banks as the sample. The results show that CSR has a positive effect on earnings management. Higher CSR activities lead banks to engage more in earnings management activity. Indonesian banks arguably use their discretions to increase CSR activities to improve bank image. However, banks also use their discretions to engage in greater earnings management activities. Using the stakeholder theory argument (Donaldson and Preston 1995, Roberts 1992) that explains that banks manage their earnings to satisfy various shareholders' interests because of these stakeholders' pressure. Thus, banks aggressively manage earnings to enhance earnings by using their discretions.

\section{References}

Alsaadi A, Ebrahim MS, Jaafar A (2017) Corporate social responsibility, shariah-compliance, and earnings quality. Journal of Financial Services Research 51 (2): 169-194.

https://doi.org/10.1007/s10693-016-0263-0

Awuy VP, Sayekti Y, Purnamawati I (2016) Pengaruh Pengungkapan Corporate Social Responsibility (CSR) Terhadap Earnings Response Coefficient (ERC) (Suatu Studi Empiris Pada Perusahaan Pertambangan yang Terdaftar di Bursa Efek Indonesia Pada Tahun 2010-2013). Jurnal Akuntansi dan Keuangan 18 (1): 15-26.

Beaver WH, Engel EE (1996) Discretionary behavior with respect to allowances for loan losses and the behavior of security prices. Journal of Accounting and Economics 22 (1): 177-206. https://doi.org/10.1016/S0165-4101(96)00428-4

Chih H-L, Shen C-H, Kang F-C (2008) Corporate social responsibility, investor protection, and earnings management: Some international evidence. Journal of Business Ethics 79 (1): 179-198. https://doi.org/10.1007/s10551-007-9383-7

Cho E, Chun S (2016) Corporate social responsibility, real activities earnings management, and corporate governance: evidence from Korea. Asia-Pacific Journal of Accounting \& Economics 23 (4): 400-431.

https://doi.org/10.1080/16081625.2015.1047005

Donaldson T, Preston LE (1995) The stakeholder theory of the corporation: concepts, evidence, and implications. Academy of management review 20 (1): 65-91. https://doi.org/10.5465/amr.1995.9503271992

Fauzi H, Idris KM (2009) The relationship of CSR and financial performance: New evidence from Indonesia companies. Issues in Social and Environmental Accounting 3 (1): 66-87. https://doi.org/10.22164/isea.v3i1.38

Fitriani H, Setiany E (2014) Pengaruh voluntary disclosure of financial information dan CSR Disclosure terhadap Earning Response Coefficient. Jurnal Akuntansi dan Bisnis 14 (2). https://doi.org/10.20961/jab.v14i2.158

Gargouri RM, Shabou R, Francoeur C (2010) The relationship between corporate social performance and earnings management. Canadian Journal of Administrative Sciences 27 (4): 320-334. https://doi.org/10.1002/cjas.178 
Gras-Gil E, Manzano MP, Fernández JH (2016) Investigating the relationship between corporate social responsibility and earnings management: Evidence from Spain. BRQ Business Research Quarterly 19 (4): 289-299. https://doi.org/10.1016/j.brq.2016.02.002

Grougiou V, Leventis S, Dedoulis E, Owusu-Ansah S (2014) Corporate social responsibility and earnings management in U.S. banks. Accounting Forum 38 (3): 155-169. https://doi.org/10.1016/j.accfor.2014.05.003

Hidayat WY, Kakinaka M, Miyamoto H (2012) Bank risk and non-interest income activities in the Indonesian banking industry. Journal of Asian Economics 23 (4): 335-343. https://doi.org/10.1016/j.asieco.2012.03.008

Hong Y, Andersen ML (2011) The relationship between corporate social responsibility and earnings management: an exploratory study. Journal of Business Ethics 104 (4): 461-471. https://doi.org/10.1007/s10551-011-0921-y

Kim Y, Park MS, Wier B (2012) Is earnings quality associated with corporate social responsibility? The Accounting Review 87 (3): 761-796. https://doi.org/10.2308/accr-10209

Law Nu.25/2007. Law of the Republic of Indonesia concerning Capital Investment.

Law Nu.40/2007. Law of the Republic of Indonesia concerning Limited Liability Company.

Liu M, Shi Y, Wilson C, Wu Z (2017) Does family involvement explain why corporate social responsibility affects earnings management? Journal of Business Research 75: 8-16. https://doi.org/10.1016/j.jbusres.2017.02.001

Martínez-Ferrero J, Gallego-Álvarez I, García-Sánchez IM (2015) A Bidirectional analysis of earnings management and corporate social responsibility: the moderating effect of stakeholder and investor protection. Australian Accounting Review 25 (4): 359-371. https://doi.org/10.1111/auar.12075

Muttakin MB, Khan A, Azim MI (2015) Corporate social responsibility disclosures and earnings quality: Are they a reflection of managers' opportunistic behavior? Managerial Auditing Journal 30 (3): 277-298. https://doi.org/10.1108/MAJ-02-2014-0997

Oeyono J, Samy M, Bampton R (2011) An examination of corporate social responsibility and financial performance: A study of the top 50 Indonesian listed corporations. Journal of Global Responsibility 2 (1): 100-112. https://doi.org/10.1108/20412561111128555

Prior D, Surroca J, Tribó JA (2008) Are socially responsible managers really ethical? Exploring the relationship between earnings management and corporate social responsibility. Corporate Governance: An International Review 16 (3): 160-177. https://doi.org/10.1111/j.1467-8683.2008.00678.x

Roberts RW (1992) Determinants of corporate social responsibility disclosure: An application of stakeholder theory. Accounting, Organizations, and Society 17 (6): 595-612. https://doi.org/10.1016/0361-3682(92)90015-K

Sarumpaet S (2006) The relationship between environmental performance and financial performance of Indonesian companies. Jurnal Akuntansi dan Keuangan 7 (2): 89-98.

Scholtens B, Kang F-C (2013) Corporate social responsibility and earnings management: evidence from Asian Economies. Corporate Social Responsibility and Environmental Management 20 (2): 95-112. https://doi.org/10.1002/csr.1286

Setiawan D, Bandi B, Phua LK, Trinugroho I (2016) Ownership structure and dividend policy in Indonesia. Journal of Asia Business Studies 10 (3): 230-252. https://doi.org/10.1108/JABS-05-2015-0053

Setiawan D, Hapsari RT, Wibawa A (2018) Dampak Karakteristik Dewan Direksi terhadap Pengungkapan Corporate Social Responsibility pada Perusahaan Pertambangan di Indonesia. Mix: Jurnal Ilmiah Manajemen 8 (1): 1-15. https://doi.org/10.22441/mix.2018.v8i1.001

Shafer WE (2015) Ethical climate, social responsibility, and earnings management. Journal of Business Ethics 126 (1): 43-60. https://doi.org/10.1007/s10551-013-1989-3

Siregar SV, Yanivi B (2010) Corporate social reporting: empirical evidence from Indonesia Stock Exchange. International Journal of Islamic and Middle Eastern Finance and Management 3 (3): 241-252. https://doi.org/10.1108/17538391011072435

Statistics_Indonesia (2018) Economic Report on Indonesia.

Sun N, Salama A, Hussainey K, Habbash M (2010) Corporate environmental disclosure, corporate governance, and earnings management. Managerial Auditing Journal 25 (7): 679-700. https://doi.org/10.1108/02686901011061351

Untoro W, Permatasari W, Trinugroho I, Setiawan D (2017) Past performance, family business, and CEO succession: the case of Indonesia. International Journal of Trade and Global Markets 10 (2-3): 236-250. https://doi.org/10.1504/IJTGM.2017.086071

Wang X, Cao F, Ye K (2018) Mandatory Corporate Social Responsibility (CSR) reporting and financial reporting quality: evidence from a quasi-natural experiment. Journal of Business Ethics 152 (1): 253-274. https://doi.org/10.1007/s10551-016-3296-2 